Zorica Kuburić

UDC 159.923.5-053.5/.6

Filozofski fakultet Univerziteta u Novom Sadu

$37.018 .1-053.5 / .6$

zoricakuburic@gmail.com

$37.01: 271.2$

Originalan naučni rad

\title{
KONKRETIZACIJA POJMA LJUBAVI U TEOLOŠKIM PORUKAMA I VASPITNIM POSTUPCIMA RODITELJA ${ }^{1}$
}

$\mathrm{Na}$ osnovu empirijskih istraživanja vaspitnih postupaka roditelja $\mathrm{u}$ procesu socijalizacije i Ronerove teorije roditeljskog prihvatanja-odbacivanja, u radu se tematizuje pojam ljubavi. U vaspitnim postupcima roditelja koje dete percipira prepoznaje se ljubav kao motiv koja čini da se dete oseća prihvaćenim. Odbačena deca akumuliraju strah i formiraju negativnu sliku o sebi. Porodica posreduje između prihvaćenog vrednosnog sistema religijske kulture kojoj pripada i novih generacija u procesu socijalizacije. Posmatrano iz ugla hrišćanske religije, idalni pojmovi su bog i ljubav kao sinonimi. Iskustvo s roditeljima i značajnim osobama u ranom detinjstvu povezana su s teorijskim konceptom odnosa prema autoritetu i njegovoj moći. Na teorijskom planu, u okviru učenja prepliću se dve ideje o Bogu, onome koji je po svojoj prirodi ljubav, koji voli, štiti, prašta, spasava i/ili onome koji kontroliše, kažnjava, sudi i uništava. Tako se ljubav i strah susreću i u religijskom iskustvu, konkretizuju se u religijskoj obrednoj praksi i živi u svakodnevnom životu porodice preko vaspitnih postupaka u procesu socijalizacije.

Ključne reči: ljubav, strah, prihvaćenost, odbačenost, vaspitni postupci, roditelji, Bog.

\section{ŠTA LJUBAV JESTE U TEORIJSKOM I PRAKTIČNOM DISKURSU}

Baveći se ovom temom, pokušavam da razumem ljubav kao odnos koji povezuje ljude i čini mogućim formiranje zajednice, počevši od rodbinskih zajednica, verskih zajednica pa sve do najintimnijeg ljudskog odnosa koji se zove bračna

1 Rađeno u okviru projekta „Promene u društvenoj strukturi i pokretljivosti kao činioci evropskih integracija Republike Srbije, sa posebnim osvrtom na AP Vojvodinu“ broj 179053 (2011-2014) koje finansira Ministarsvo za nauku i tehnološki razvoj Republike Srbije. 
zajednica. Mreže međuljudskih odnosa isprepletene su brojnim osećanjima, koja ovom prilikom zanemarujemo da bismo se usredsredili samo na ljubav kao najlepši i najpoželjniji odnos.

U potrebi za definisanjem samog pojma ljubavi citiraću reči Meše Selimovića u knjizi Derviš i smrt: na pitanje dečaka „Može li jedna testija zahvatiti vodu velikog mora?" sledi odgovor „Testijom ne možeš zahvatiti celo more, ali i to što zahvatiš i to je more." U ovom edukativnom dijalogu, Meša Selimović prenosi ideju da je konkretizacija pojma moguća u svakom deliću neke celine. Iskustvo ljubavi svakog pojedinca je konkretna varijacija teme o kojoj se najviše govori. Svaki pojedinačni govor o noj samo je jedna kap vode iz tog prelepog okeana koji se zove ljubav.

Erih From u knjizi Umeće ljubavi (From, 1965), postavlja pitanje da li je ljubav umeće ili osećanje. Ako jeste umeće, ona zahteva znanje i trud i podleže procesu učenja. Ovaj optimistički pristup o mogućnosti učenja umeća ljubavi upućuje nas na onoga koji poučava i prenosi veštinu na nekoga ko je može usvojiti. U tom dijaloškom procesu, ljubav ima neke svoje specifičnosti o kojima želim da u ovom radu govorim u okviru ranog učenja i teorije socijalizacije.

Proces ovaladavanja umećem traje i ima svoja dva prepoznatljiva dela: ovladavanje teorijom i ovladavanje praksom. Dakle, možemo govoriti o teorijskoj i praktičkoj strani pojma ljubavi. A sama praktička ljubav u svom motivacionom jezgru može biti zasnovana više na empatiji ili, pak, više na normativnom aspektu (Kuburić, 1997). Takođe, u kontekstu drugih motiva, da bi ljubav bila prepoznatljiva u praksi, neophodno je da u sistemu vrdnosti ljubav ima svoje mesto, tj. prepoznatljivu hijerarhijsku strukturu. Abraham Maslov (1982) je pronašao mesto za ljubav u središnjoj poziciji između egzistencijalnih potreba i samoaktualizacije. Vladeta Jerotić (1996a) u knjizi Samo dela ljubavi ostaju, upućuje na večnu vrednost praktičnog aspekta ljubavi.

U pokušaju definisanja pojma ljubavi poći ćemo od njene strukture, od onoga što ona jeste u svom manifestnom obliku, $u$ konkretizaciji koja se očitava $\mathrm{u}$ : verbalnom iskazu, iskustvu susreta, fizičkom pokretu, ponašanju, poklonjenom predmetu, dužini posvećenog vremena i nameri koja se usmerava na dobro. Dobrobit koja proizlazi iz ljubavi je uvek relaciona. Ako bismo ljubav definisali iz njene funkcije, više nego strukture, njena definicija bi bila da je ljubav integrativna moć, snaga povezivanja razdvojenih u jednu duhovnu celinu. Ljubav odgovara na problem 
ljudske egzistencije, daje smisao koji uliva sigurnost, omogućava rast u integraciji sebe samog u jedinstveno, samostalno biće u trenutku kada su se drugi dovoljno akumulirali i omogućili formiranje vlastitog ja.

Kriterijumi za klasifikaciju unutar pojma mogu biti različiti. Ako je kritierijum objekat ka kome je ljubav usmerena imamo sledeće vrste ljubavi: bratska ljubav, majčinska ljubav, erotska ljubav, ljubav prema sebi, ljubav prema Bogu. ljubav prema roditeljima, ljubav prema prijateljima, ljubav prema neprijateljima.

Ako je kriterijum podele izvor iz koga se ljubav emituje, možemo govoriti o: Božanskoj ljubavi i ljudskoj ljubavi, ljubav Stvoritelja i ljubav čoveka, stvorenog bića. Božanska ljubav je, onako kako je ja razumem, bezuslovna; nemerljiva, večna, savršena, sveprisutna. Ljudska ljubav je egalitarna, recipročna, zaslužena, nesavršena, dimenzionalna, varijabilna, selektivna. Dakle, priroda Bića uslovljava kvalitet same ljubavi.

Ako se upitamo o posledicama ljubavi dolazimo do odgovora da ljubav čini osoobu sigurnom. Ljubav pobuđuje veseo duh, dakle, radost je plod ljubavi (Cessario, 2007: 99). Ako ljubav i radost idu zajedno onda možemo preuzeti ideju da je strah povezan s grehom na što upućuje Žan Delimo u svojoj knjizi Greh i strah (Delimo, 1986). Osim ovog emotivnog učinka, ljubav, kao emotivni kapital, ima tendenciju da se ponovo vraća drugima. Ljubav izaziva potrebu da se drugi poštuje i ljubi, a značajni drugi ponovo su roditelji. Tako se posledice roditeljske ljubavi vraćaju, te se na obostranu radost susreću roditelji i deca u porodičnom krugu.

Međutim, budući da niko nije savršen, princip realnosti kad tad osvesti dete iskustvom izdaje. U tom raskoraku između realnosti koja nije savršena i idealnih pojmova koji se, kada je upitanju ljubav, konkretizuju u reči Bog, stoji razapeti čovek. Đuro Šušnjić (1998) govoreći o religijskim simbolima, upravo jedno značenje krsta vidi u čovekovom uspravnom stavu i raširenim rukama. U Bibliji je ljubav osnovni pojam kojim se naziva Bog: 1. Jovanova 4, 8. „A koji nema ljubavi ne poznaje Boga, jer je Bog ljubav.“ Ako se pitamo za značenje ljubavi u kontekstu Biblije imamo odgovor u Poslanici Rimljanima 13, 10. „Ljubav ne čini zla bližnjemu, daklem je ljubav izvršenje zakona.“ Ako je ljubav izvršenje zakona postavljamo pitanje kog zakona. U Mateju 22, 36-40: „Učitelju koja je zapovest najveća u zakonu? A Isus reče mu: Ljubi Gospoda Boga svojega svime srcem svojim i svom dušom svojom i svom misli svojom. Ovo je prva i najveća zapovest, a druga je kao i ova ljubi bližnjega 
svojega kao samoga sebe. O ovim dvema zapovestima visi sav zakon i proroci.“

Karakteristike vremena koje je označeno sintagmom „poslednje vreme“ su nedostatak ljubavi. Hristove reči u Jevanđelju po Mateju 24, 12: „I što će se bezakonje umnožiti, ohladneće ljubav mnogih. Ali koji pretrpi do kraja blago njemu“. U ovim rečima prepoznajemo dimenzionalnost ljubavi, koja na jednom kraju ima odlike vruće, goruće ljubavi a na drugom kraju hladnu ljubav. Zanimljivo je da je hladna ljubav postavljena u istom stihu s odlikom kvantitativnog umnožavanja bezakonja. Paradoks ljubavi prema neprijatelju (Matej 5, 44), koju Hristos zahteva od svojih sledbenika, jeste $u$ tome što tek tu shvatamo da zapravo ljubav prihvata datost. Ljubav je odnos koji prihvata osobu onakva kakva jeste. To znači da je ljubav po svojoj prirodi bezuslovna. Kako onda shvatiti vaspitne postupke roditelja koji su motivisani ljubavlju a zahtevaju prevazilaženje vlastite datosti u razvoju i promeni? U pokušaju da odgovorim na ovo pitanje uočila sam još jedan paradoks u praksi, a to je kada roditelji dobiju dete sa smetnjama u razvoju, u stanju su da pokažu, posebno majka, apsolutno prihvatanje i žrtvovanje za svoje dete koje prihvataju bezuslovnom ljubavlju. Međutim, usled brojnih nezadovoljstava životm, događa se da roditelji odbacuju i uslovljavaju sasvim zdravu decu. Između tih krajnosti negde, odvija se realni život i tada ljubav postaje merljiva kategorija.

\section{STRAH KAO SUPROTNOST LJUBAVI}

Budući da je poimanje autoriteta akumulacija iskustva s roditeljima, $s$ jedne strane, a s druge teorijska refleksija teoloških učenja o prirodi Boga kao roditelja čovečanstva, bitno je razmotriti oba aspekta. Ovozemaljsko iskustvo s roditeljima i značajnim osobama u ranom detinjstvu povezana su s teorijskim konceptom odnosa prema autoritetu i njegovoj moći. Na teorijskom planu, u okviru učenja prepliću se dve ideje o Bogu. Bog je Biće koji je po svojoj prirodi ljubav, koji voli, štiti, prašta, spasava. Međutim, u isto vreme Bog je predstavljen i kao Biće koje kontroliše, kažnjava, sudi i uništava. Za one koji Boga doživljavaju primarno kao strogog sudiju, karakteristično je da koriste različite metode kao što su dobra dela, asketski način života, prinošenje raznih žrtava, da bi na neki način zaslužili spasenje. Čovek koji na ovaj način služi Bogu čini to iz straha. Tako se ljubav i strah susreću i u religijskom iskustvu, konkretizuje se u religijskoj praksi sve do vaspitnih postupaka 
u porodičnom krugu u procesu socijalizacije (Kuburić, 2008).

„Čovek koji služi Bogu iz straha ne vidi sebe kao relativnog subjekta u svom odnosu sa Bogom, već više kao objekta religije. Takav čovek uvek ima pred sobom sliku Boga koji je spreman da kazni onog koji ne ispunjava norme, zakone, razne crkvene ili pak neke druge religijske propise i običaje. On ne poznaje Boga koji je ljubav, već smatra Boga Bićem koji se na neki načim mora umilostiviti, pred kojim se nešto mora zaslužiti“ (Bodiroga, 2004: 57).

Osim ovog straha od Božje kazne koja proizlazi iz Njega kao pravednog Bića, kao odgovr na greh koji čovek počini, postoji strah od sudbine koji se "ogleda u strahu od svih mogućih vrsta pretnji ljudskom bivstvovanju koje mogu da nastanu u budućnosti." (Jerotić, 1996: 38).

Isus Hristos prilikom rastanka s učenicima poručuje im: Da se ne plaši srce vaše, verujte Boga, i mene verujte“ (Jovan 14,1). Apostol Pavle piše crkvi u Rimu da se Božji zakon može poštovati samo onda ako je ljubav motiv. „Ljubav ne čini zla bližnjemu; dakle je ljubav izvršenje zakona.“ (Rimljanima 13,10). Najlepša pesma o ljubavi zapisana je u 1. Korinćanima 13 poglavlje: „Ljubav dugo trpi, ljubav je dobra, ona ne zavidi, ljubav se ne hvali, ne nadima se, ne ponaša se nepristojno, ne traži svoje, ne ljuti se, ne uračunava zlo, ne raduje se nerpavdi, ali se raduje sa istinom. Ona sve snosi, sve veruje, svemu se nada, sve trpi. Ljubav ne prestaje nikada.“

Apostol Jovan kaže da se ljubav i strah prema Bogu međusobno suprostavljaju, te da se onaj, koji služi Bogu iz ljubavi, oslobodio mučnog osećanja straha. „U ljubavi nema straha, nego savršena ljubav izgoni strah napolje, jer strah ima muku. A ko se boji nije savršen u ljubavi.“ (Jovan 4,18.19). Dajući komentar na ove stihove Džon Stot (Stott, 1991) kaže da su ljubav i strah nespojive kao što su to voda i ulje. Bog se može istovremeno i ljubiti i poštovati, ali Mu se ne može u ljubavi pristupiti i istovremeno se kriti od Njega zbog straha. Poznati Ruski filozof, Nikolaj Berđajev (1982), piše da zbog Hristove smrti na krstu i Njegovog vaskrsenja naš život treba da bude radost i da zbog toga Bogu služimo iz zahvalnosti. Strah nije prisutan u životu religioznog čoveka. Jedan od bitnih ciljeva religije jeste pobeda nad strahom.

Da li je strahopoštovanje samo jedna vrsta religijskog straha? Apostol Jovan u Otkrivenju piše: "Bojte se Boga i podajte mu slavu, jer je došao čas suda Njegova; i poklonite se onome koji je stvorio nebo i zemlju." (Otkrivenje, 14,7) Šta znači bojati se Boga? Izvorna grčka reč na ovom mestu upotrebljava se u smislu dolaska k Bogu 
sa dubokom naklonošću.

Mudri Solomun je strahopoštovanje izrazio sledećim rečima: "Strah je Gospodnji mržnja na zlo” (Priče 8,13); „Strah je Gospodnji izvor životu“ (Priče 14,27); Strahom se čovek uklanja od zla, što ima zaštitnu funkciju. „Odlučno i sa ljubavlju stajati uz Božju istinu i verno ispunjavati obećanja i dužnosti, znači uklanjati se od zla. Služiti Bogu iz ljubavi diveći se veličini Njegovog karaktera i moći, i u toj službi osećati radost, to je biblijski princip služenja Bogu iz straha, odnosno strahopoštovanja“ (Bodiroga, 2004: 62).

Borislav Lorenc pišući o religijskom doživljavanju razlikuje stanje prijatnosti I stanje neprijatnosti. Neprijatna stanja su: mučno osećanje bola, tuge, jada, osećanje nemanja i dr. U prijatna osećanja pored radosti, sreće, mira, spokojstva i dr, dolazi i strahopoštovanje. "Na višem stupnju religioznog života strah se javlja samo u obliku strahopoštovanja bez koga nema prave pobožnosti. Strahopoštovanje je osećanje koje se javlja na vrhuncu ljudskog razvića. Primitivni strah od demona ustupa, na višem stupnju religioznog razvića, mesto strahopoštovanju... Najviši motiv u pravcu moralnog usavršavanja je strahopoštovanje pred Bogom, a ne kazna i nagrada. U vezi sa strahopoštovanjem je i poniznost, takođe jedan fini i dubok doživljaj čija dubina odgovara dubini pobožnosti." (Lorenc, 1938: 85.88).

\section{PORODICA JE MESTO RAĐANJA LJUBAVI}

Porodica je mesto svih rađanja. Ona je mesto početaka individualne svesti. Zajednica u kojoj se rodi dete zove se porodica, zapravo rađanjem deteteta formira se porodica. Jedna ljubav, muškarca i žene, kakva god ona bila, prouzrokovala je ljubav koja se razvija prema detetu. Deca koja izrastaju iz različitih porodica nose sa sobom bogatstvo njihovog uticaja i organizuju vlastite živote na slične načine. Slika o sebi koju svaki pojedinac nosi sa sobom, takođe nastaje i formira se u tom prvom socijalnom ogledalu, u svesti roditelja, u porodici, u međusobnoj interakciji.

Porodica, iako najmanja društvena jedinica, veoma je složena pojava, koja objedinjuje različite aspekte ljudskog života. Svaki pojedinac doživljava porodicu na sopstveni način zavisno od toga u kakvoj je porodici odrastao. Anđelka Milić piše: "Umesto termina porodica u upotrebi su sve do XVIII veka bili raznovrsni termini. Težište jednih je na zajednici svakodnevnog života bez obzira na srodničke relacije 
(kuća, domaćinstvo, domaća zajednica), a drugih na srodničkim relacijama tj. poreklu, bez obzira na aktualnu pripadnost određenoj kućnoj, odnosno domaćoj zajednici (loza, srodstvo, rod, rodbina)" (Milić, 1988. str. 10). U Sociološkom rečniku čitamo da je porodica jedn aod malih, primarnih društvenih gurpa koju čine dva elementa koji variraju u istorijki pormenjivim srazmerama: (1) zajednički život i rad pod istim krovom grupe ljudi i (2) srodnička povezanost između njih (Milić, 2007).

Porodica je oduvek imala mnogobrojne funkcije koje su u različitim razdobljima a i mestima života imale manju ili veću važnost. Istorijski gledano, porodične funkcije su se takođe menjale, redukovale, ponovo vraćale u periodima društvenih kriza, a neke funkcije ostaju univerzalne i prevazilaze istorijske granice, društvene sisteme i porodične organizacije. Za savremenu porodicu karakteristična je redukcija funkcija i to, pre svega, ekonomskih, a težište se prebacuje na psihosocijalnu sferu, što je u skladu sa položajem porodice u savremenom društvu (Golubović, 1981).

Među mnogobrojnim izvorima socijalizacije porodica predstavlja jedan od najvažnijih (Đorđević, 1991), obzirom da se primarna socijalizacija odvija u toku najranijeg detinjstva. Porodica ima skoro ekskluzivnu kontrolu nad detetom u njegovim najranijim i najvažnijim godinama oblikovanja. U njoj dete uči jezik i prve obrasce ponašanja, stiče početne radne navike i usvaja polne stereotipe koji važe u datom društvu. Pored toga, ono se u njoj uči običajima i pravilima, stiče temelje obrazovanja i užiova zaštitu.

Pregled stručne literature, prema Popadiću (1992) pokazuje da, bilo koji segment celovitog procesa socijalizacije izdvojili, istraživači obavezno porodicu smatraju glavnim agensom socijalizacije. Za tako naglašen značaj porodice lako je naći puno razloga. Prvo, porodica dugo vremena predstavlja sav detetov socijalni svet. Porodica zadovoljava sve detetove potrebe, poučava ga, interpretira mu realnost. Porodica svakodnevno vrši i nameran i nenameran uticaj na dete, a pri tom ona zbog snažnih emocionalnih veza koje se u porodici uspostavljaju, poseduje najsnažnije nagrade i kazne pri oblikovanju detetovog ponašanja.

\section{VASPITNI POSTUPCI RODITELJA}

U okviru porodične psihodinamike posebno je značajno ponašanje roditelja 
prema deci. Ponašanje roditelja prema deci pod uticajem je društva u kom porodica formira svoj identitet i stil ponašanja. Još je Kurt Levin (Lewin, 1948) istakao povezanost opšte političke klime i ideologije sa odnosom prema deci na različitim nivoima obrazovanja. Po njemu, demokratski odnos podrazumeva uvođenje razumnog dogovora i argumenta $\mathrm{u}$ odnos sa detetom, dok autoritaran odnos podrazumeva neravnopravnost, komandovanje ili poslušnost. Istovremeno, uz demokratski odnos ide i naglasak na rano osamostaljivanje deteta, od koga se očekuje da ovlada određenim aktivnostima. Istraživanja otkrivaju da demokratičnije vaspitana deca pokazuju veću samostalnost i preduzimljivost. Razvoju kreativnosti pogoduje brižna, topla i demokratična atmosfera, bezuslovno prihvatanje i empatičko razumevanje deteta, prihvatanje njegove unutrašnje psihičke slobode i individualnosti.

Lacković-Grgin (1982) smatra da su autori različito operacionalizovali varijable roditeljskog ponašanja. Neki su se više zanimali za dimenzije kao što su: prihvatanje-odbacivanje deteta, dominacija-submisivnost, autonomijakontrola, ljubav-neprijateljstvo. Drugi autori su se pak više zanimali za sindrome ponašanja kao što su: demokratičnost, autoritativnost, popustljivost. Ona ističe da su najčešće proučavane dimenzije prihvatanje-odbacivanje, kao indikator roditeljskog emotivnog odnosa prema detetu, i kontinuum autonomija-kontrola, kao pokazatelj disciplinirajućeg ponašanja.

Kota (Cota, 1982) je prikupila podatke iz literature o tome koje tipove ponašanja roditelja autori smatraju poželjnim a koje nepoželjnim, i dobila da su prihvatanje i toplina roditelja često spominjani kao poželjan oblik ponašanja, a roditeljsko odbacivanje kao nepoželjan oblik.

Olga Arežina (1991) navodi da istraživanja o roditeljskim odnosima u porodicama sa decom ranog uzrasta u Beogradu pokazuju da su roditelji bili svesni potrebe dece za mirnom, toplom emocionalnom atmosferom u porodici kao presudne za povoljan razvoj deteta. Međutim, $\mathrm{u}$ istraživanju na uzorku dece iz sociokulturno lišenih porodica ili socijalno ugroženih porodica, upravo takva povoljna "dobra" atmosfera u porodici je ono što deci nedostaje. Istovremeno, pokazuje se da su vaspitači, pa i druga deca donekle, svesni ove činjenice, sa nastojanjem da deci na izvestan način nadoknade ono što im porodica ne pruža.

Deca prihvataju svoju porodičnu sredinu, prilagođavaju joj se i doživljavaju je kao prirodnu sredinu iz koje potiču. Deci je svojstvena adaptabilnost. Međutim, 
da li su roditelji spremni da prihvate svoje dete? Na koji sve način roditelji pokazuju detetu da je prihvaćeno ili pak odbačeno? Da li je moguće da dođe do nesporazuma?

Roner (Rohner, 1984) smatra da roditeljsko prihvatanje, odnosno odbacivanje, ima vrlo veliko značenje za razvoj ličnosti dece kao i za njihovo funkcionisanje u odraslom dobu. Ronerova teorija roditeljskog prihvatanja i odbacivanja (Parental Acceptance and Rejection Theory - PART), jeste teorija socijalizacije koja pokušava da objasni i predvidi posledice roditeljskog ponašanja na dimenziji roditeljske osećajne topline, na čijem se jednom kraju nalazi prihvaćenost, a na suprotnom odbačenost deteta. Roditelji koji prihvataju svoju decu opisani su kao oni koji pokazuju svoju ljubav i osećanja prema deci fizički i, ili verbalno. Fizički ljubav se moše pokazati ljubljenjem, grljenjem, milovanjem itd. a verbalno pohvalom, komplimentom, davanjem pozitivnih iskaza o detetu itd. Svi ti različiti načini pokazivanja ljubavi, povezano ili pojedinačno, čine da se dete oseća voljenim i prihvaćenim.

Roditelji koji odbacuju svoju decu opisani su kao oni koji ne odobravaju ponašanje deteta, pružaju često otpor prema deci, zameraju deci na mnogo čemu i ogorčeni su. U mnogim slučajevima oni vide svoje dete kao teret i u poređenju s drugom decom doživljavaju ga kao beskorisno i nesposobno. Odbacivanje se prema Ronerovoj teoriji, manifestuje na dva osnovna načina: u obliku roditeljskog neprijateljstva i agresivnosti s jedne strane i zanemarivanja i ravnodušnosti s druge strane. I ovde postoji bezbroj načina na koje roditelji u detetu razvijaju osećanje odbačenosti. Agresivni roditelji svoje neprijateljsvo izražavaju fizički, npr. udaranjem deteta, mogu ga tući nogom, gurnuti, štipati, ugristi, daviti, grepsti ili opeći; i verbalno, izražavanjem besmislenih, neljubaznih i okrutnih pojedinosti svojoj deci ili o svojoj deci. Oni mogu proklinjati, psovati i biti sarkastični prema deci. Indiferentni ili nemarni roditelji ne polažu pažnju na potrebe deteta, fizički i psihički udaljeni su od dece, nepristupačni su, ignorišu dečje pozive na pažnju, skloni su da budu neodgovorni prema dečjim fizičkim i emotivnim potrebama. Takođe mogu da pokažu i restriktivnu zabrinutost za dobrobit svoje dece. Indiferentni roditelji skloni su da poklanjaju malo pažnje detetu i da provode minimum vremena s njim. Takvi roditelji često zaboravljaju obećanja koja su dali svojoj deci, i ne primećuju neke druge detalje i potrebe koje su značajne za sreću i razvoj njihove dece. Roner smatra da ova oba oblika ponašanja roditelja, i neprijateljstvo-agresivnost i indiferentnostzanemarivanje, možemo tretirati kao otvorene izraze odbijanja, jer oba sadrže 
odsutnost roditeljskog dodira i vezanosti i podstiču decu da se osećaju nevoljenom i odbačenom.

Prema ovoj teoriji, roditeljsko prihvatanje ili odbacivanje ima snažne posledice, posebno kad je od individue opaženo, na ponašanje i ličnost dece kao i na funkcionisanje ličnosti odraslog koji za sebe kaže da je bio "odbačeno dete" (Rohner, 1984). Istraživanja i klinički zapisi u Americi podupiru ovo očekivanje da se odbacivanje može uplesti u čitav niz psihijatrijskih bolesti poremećaja u ponašanju, uključujući neuroze, delinkvenciju, psihosomatske reakcije kao što su različite alergije, školski problemi, mucanje, poremećaji slike o vlastitom telu itd. (Rohner and Nielsen, 1978).

Uvažavajući ove posledice roditeljskog prihvatanja-odbacivanja, Rohner je svoja istraživanja usmerio na dispozicije ličnosti, osobine koje se mogu očekivati kao posledica roditeljske agresivnosti ili zanemarivanja u svim kulturama. Deca koja su odbacivana ili emotivno zlostavljana i povređivana, sklona su znatno više no prihvaćena deca da budu neprijateljski raspoložena i agresivna ili da imaju problema s kontrolom neprijateljstva i agresivnosti; da budu zavisna ili "odbrambeno nezavisna", što je povezano sa stepenom odbacivanja; da imaju oslabljeno osećanje samopoštovanja i samoadekvatnosti; da su emotivno nestabilna, ravnodušna i da imaju negativan pogled na svet. Svaka od ovih dispozicija ličnosti rezultat je odbacivanja, jer sledeći Mida (Mead, 1934), što je preuzeto u teoriji PART, svi mi skloni smo da vidimo sebe onako kako su nas "značajni drugi” videli, i ako su nas naši roditelji kao najznačajniji "drugi” odbacivali kao decu, mi smo skloni da definišemo sebe kao nezaslužne ljubavi, čak i kao bezvredna i neadekvatna ljudska bića.

Transgeneracijski prenos takođe je značajan. Odrasli koji su kao deca odbacivani, imaju vrlo snažnu potrebu za ljubavlju, ali često njihova sposobnost da uzvrate ljubavlju oštećena je zato što su mnogi od njih postali više-manje emotivno usamljeni i nesposobni da odgovore na potencijalno prisne međuljudske odnose. Prema PART očekuje se da će vlastitu decu značajno više odbacivati roditelji koji su kao deca bili odbacivani, nego oni roditelji koji su se kao deca osećali prihvaćenima. $\mathrm{Na}$ taj način krug odbacivanja teži da bude ovekovečen u konstelaciji opisanih dispozicija. Empirijska istraživanja pokazala su da su takvi roditelji i sami bili zanemarivani i da im je bila uskraćena ljubav i toplina u detinjstvu (Rohner and Rohner, 1980a). Međutim, istraživanje koje sam radila s religioznim porodicama 
(Kuburić, 1995; 2008) odbačeni pojedinci koji su putem konverzije upoznali Boga ljubavi, znatno više iskazuju ljubav prema svojoj deci zahvaljujući konceptu osećanja prihvaćenosti od Boga.

Izgleda sasvim jasno da roditeljska ljubav i toplina, kao i nedostatak te ljubavi, imaju snagu da oblikuju ljudsko ponašanje na svim meridijanima. Uprkos tome neka deca kao da su sposobnija od drugih da uspešno izbegnu ili u određenom stepenu savladaju štetne efekte roditeljskog odbacivanja i emotivnog povređivanja. Koja su to deca? Šta je to što u njima smanjuje inače vrlo štetne efekte roditeljskog odbacivanja? Odgovor na ovo pitanje tema je koja se danas sve više proučava u okviru istraživanja rezilijencije (Volin, Volin 1996). Prema filogenetskom modelu Ronerove teorije (Rohner, 1978), možemo pretpostaviti da stepen dečje otpornosti prema odbacivanju zavisi od nekih socijalno-situacionih činioca kao i od kognitivnih sposobnosti "boraca" da "prerade" i učine manje bolnim ono što je opaženo (Rohner and Rohner, 1979). Borci mogu svojim svesnim i podsvesnim mentalnim aktivnostima da izbegnu posledice roditeljskog odbacivanja. Sposobnost deteta da se bori protiv rđavog uticaja roditeljskog odbacivanja razvija se ako se pronađu bliski prijatelji, tada će mu emotivna podrška prijatelja pomoći da izađe na kraj s opaženim odbacivanjem. Uspostaviti tople i poverljive odnose s osobom koja ume da voli, to emotivno utočište pomoći će da se preboli odbacivanje. Neka deca pokušavaju da provedu minimum vremena sa svojim roditeljima koji ih odbacuju, i to im pomaže da u znatno manjem stepenu iskuse uticaj odbacivanja nego deca koja se dugo zadržavaju u toj negativnoj emotivnoj atmosferi.

U knjizi Porodica i psihičko zdravlje dece istraživala sam uticaj porodice na psihičko zdravlje dece (Kuburić, 2009). Rezultati pokazuju da se psihičko zdravlje temelji na roditeljskoj ljubavi i osećanju dece da su voljena i prihvaćena, dok su psihički poremećaji povezani sa percipiranim odbacivanjem od roditelja. Ovim istraživanjem potvrđeno je očekivanje da je učestalije osećanje odbačenosti kod adolescenata koji imaju psihičkih smetnji. Ispitanici se slažu da majka pruža više topline i ljubavi nego otac, a da je otac onaj ko ih više zanemaruje. Rezultati takođe pokazuju da se psihijatrijski pacijenti razlikuju i po učestalosti porodičnih sukoba. Sukobi među roditeljima učestaliji su kod psihijatrijskih pacijenata u odnosu na opštu populaciju adolescenata. Što se tiče slike o sebi, na svim dimenzijama su pronađene statistički značajne razlike, izuzev dimenzije stavovi prema seksualnosti, 
između ispitivanih grupa. Slika o sebi odbačene dece je znatno niža od slike o sebi prihvaćene dece. Najveće razlike ispoljene su na dimenzijama emotivni ton, socijalni odnosi, porodični odnosi i psihičko zdravlje.

U knjizi Religija, porodica i mladi (Kuburić, 2008) izneti su rezultati istraživanja posredovanja religijskim vrednostima i efektima koji se upliću u psihičku strukturu dece. Relilgija nudi porodici jasan i zahtevan vrednosni sistem kako i pravila ponašanja koja takvu pordicu čine zahtevnijom, vaspitne postupke usmeravaju ka većoj kontroli, a efekti su očiti u naglašenoj moralnosti i većim nezadovoljstvom sopstvenim postignućem. Nazivajući to religijskim perfekcionizmom, smatram da je ljubav rešenje, a ona se testira upravo izazovima počinjenih grehova. Tako je greh najveći izazov ljubavi a praštanje sredstvo ponovnog uspotavljanja zajednice.

\section{ZAKLJUČAK}

O ljubavi i njenim razvojnim aspektima sve više razmišljam na osnovu akumuliranog znanja koje je zaboravilo izvore, koje se distanciralo od teorija. Ljubav i njeno nastanjivanje $u$ iskustvu svake ličnosti ima svoje razvojne faze. Prva faza je faza akumulacije ljubavi od drugih, pre svega roditelja. Ako roditelji zakažu, pojavljuje se proces privlačenja pažnje od drugih značajnih osoba ili se, u slučaju neuspeha, formira odbrambena nezavisnost kao vid zatvaranja za dalja emotivna povređivanja. Ovde je čovek najznačajniji sebi, ulaže u sebe, akumulira znanja i ljubav, dodire, ukorenjuje se. Stiče najveće bogatstvo, emotivni kapital. U ovoj fazi akumulacije značajno je da dominira JA. Svakako da je zrelost roditelja neophodna da bi mogli da nesebično poklanjaju ljubav i pažnju deci. Budući da je ljubav uvek odnos koji povezuje, u ovom slučaju povezuju se oni koji su u fazi akumulacije ljubavi s onima koji su u fazi samoostvarene ljubavi, oni koji su u potrebi da primaju i oni koji su u stanju da daju bez uzvraćanja. U tom neravnopravnom odnosu zrelosti i nezrelosti omogućen je razvoj i sazrevanje i opisuje ulogu deteta i ulogu roditelja. Ovaj odnos je progresivnog karaktera i u funkciji je razvoja. Granica između egocentrične faze razvoja i egalitarne koja joj sledi nije sasvim jasna i striktna, i moguća su kretanja u oba pravca, regresije koje dopunjavanju propušteno i proveravaju naučeno.

Druga faza razvoja je egalitarna faza ljubavi. Ljubavna razmena ravnopravnih karakteristična je za period u kome dominira MI odnos. Ovde je prepoznatljiva 
orijentacija na reciprocitet i razmenu, formiranje odnosa koji omogućava sazrevanje ličnosti, realno doživljavanje, negovanje ljubavi kroz koju se sazreva. Odns jednakih prepoznajemo obično u odnosu između dece u porodici, u odnosima među vršnjacima, u partnerskim odnosima i međuljudskim odnosima jednakih. Svakako je najjača erotska ljubav i u funkciji je integracije sopstva, dok je bratska ljubav $\mathrm{u}$ funkciji diferencijacije sebe od drugog jednakog u hijerarhijskom smislu. Ovo je zrelost koja je ispunjena sobom, na vrhuncu moći. U ovom periodu preokupiranost svakodnevnim životom i vlastim uspesima, posebno ostvarenje u intimnosti, otvara potrebu za ulaganjem ljubavi u reproduktivnom ostvarenju. Nekome se roditeljstvo desi, neočekivano i neplanirano, međutim, ono je zrelo tek kada je željeno.

Treća i poslednja faza razvoja jeste samoostvarena faza ljubavi koja omogućava nesebičnost davanja, zrelost koja se prepoznaje u sposobnosti davanja prioriteta drugome, odgovornost za partnera, decu, roditelje. To je faza moći vladanja i kontrolisanja sopstvenih nagona na zadovoljavajući način. Ovde je pojedincu najvažnije da se ostvari dobrobitit drugog. Možemo je nazvati: Faza dominacije TI odnosa. Pojedinac je spreman da se odriče, da voli i daje bez da očekuje da mu se uzvrati. Sazrevanje se postiže putem lične odluke da se i pored poraza, neuspeha, razočarenja ide dalje u razvijanju i jačanju sopstvene ličnosti.

Dakle, pređeni put sazrevanja nikada nije dovršen, paralelno se otvaraju nova polja, a stara nastavljaju da žive. U teorijskom konceptu različitih psiholoških škola prepoznajemo ideju „dete, odrasli, roditelj“ i dominaciju jednog aspekta čovekove ličnosti u određenom vremeskom razdoblju. Ono što je još značajno jeste postupak ispitivanja granica ljubavi. Kada se ispituje osoba pored nas koliko nas voli, onda se događa da se traže granice, da se ide baš tamo gde je zabranjeno. Prekršitelj ostavlja trag da bi bio pronađen. Na taj način daje šansu da bude odbačen ili prihvaćen, uprkos krivice.

U potrazi za bezuslovnom ljubavlju prolazimo kroz tri različite razvojne faze. Prva faza jeste primanje ljubavi u neograničenim količinama sve do punine samoprihvatanja i samopoštovanja. Kada se riznice emocionalnih kapaciteta popune, javlja se spremnost za emotivnu razmenu. Tada počinje drugi period u kome razmenjujemo uvek u želji da drugog usrećimo, a gle čuda, on usrećuje nas. Na kraju zrelost dostiže kapacitete davanja bez uzvraćanja, i tako se život nastavlja. Smisao koji nadahnjuje život ostvaruje se u ljubavi koja ima svoje sasvim praktične posledice. 


\section{LITERATURA}

Arežina, Olga (1991). Psihološki aspekti socijalno-zaštitne funkcije dečje zaštite. Deca i društvena kriza. Beograd: Institut za socijalnu politiku.

Berđajev, N. (1982). Nova religijska svest $i$ društvena realnost. Beograd, Ljubljana: IRO.

Bodiroga, Radmilo (2004). Religijski strah i psihološke posledice. Religija $i$ tolerancija. 2: 55-82.

Cessario, Romanus (2007). Kreposti, Zagreb: Kršćanska sadašnjost.

Campbell R. (1977). How to really love your Child. England: Scripture Press.

Cota M. (1982). Mišljenje roditelja o nekim poželjnim i nepoželjnim oblicima ponašanja idealne majke i idealnog oca, Diplomski rad. Zagreb: Filozofski fakultet.

Delimo Ž. (1986). Greh i strah, Novi Sad: Dnevnik.

Đorđević B. (1985) Savremena porodica i njena vaspitna uloga. Beograd: Institut za pedagoška istraživanja.

Froom, E. (1965). Umeće ljubavi. Zagreb: Matica Hrvatska.

Golubović Z. (1981). Porodica kao ljudska zajednica, alternativa autoritarnom shvatanju porodice kao sistema prilagođenog ponašanja. Zagreb: Naprijed.

Jerotić V. (1996a). Samo dela ljubavi ostaju. Beograd: Manastir Hilandar.

Jerotić, Vladeta (1996b). Staro i novo u hrišćanstvu. Beograd: Istočnik.

Kuburić, Z. (1995). Slika o sebi adolescenata u protestantskoj porodici, doktorska disertacija. Beograd: Filozofski fakultet.

Kubruić Zorica (1996). Teenager's Family and his Religion. The scientific journal Facta universitatis, Series Philosophy and Sociology, I/ 3: 295 - 300.

Kuburić, Zorica (1997). Odnos između empatije i religioznosti, U: Joksimović, Gašić-Pavišić i Miočinović (ed), Vaspitanje i altruizam. Zbornik instituta za pedagoška istraživanja. Beograd, pp. 291-307.

Kuburic Zorica (1998). Image of God in Religious Experience. Facta Universitatis, Philosophy and Sociology, I/5: 471-484.

Kuburić Z. (2009). Porodica i psihičko zdravlje dece. Četvrto izdanje. Beograd: Čigoja štampa.

Kuburić, Z. and Kuburić, A. (2006). Differences between Secular and 
Spiritual Identity. Sociology, XLVIII/1: 19-37.

Lacković-Grgin K. (1982). Porodica i socijalizacija mladih - s posebnim obzirom na utjecaj otvorenih oblika roditeljskog ponašanja na dijete. U zborniku: Dani psihologije u Zadru. 1980/81, Zadar.

Lewin, K. (1948). Reslolving Social Conflicts. New York: Harper and Row.

Lorenc B. (1937, 1940). Psihologija i filozofija religije. Beograd: Geca Kon.

Maslov, Abraham (1982). Motivacija i ličnost. Beograd: Nolit.

Mead G. (1934) Mind, Self and Society, Chicago: University of Chicago Press.

Milić A. (1988). Rađanje moderne porodice. Beograd: Zavod za uđbenike i nastavna sredstva.

Milić A. (1989). Tipovi porodice, Pedagoška enciklopedija. Beograd, Zagreb, Sarajevo, Titograd, Novi Sad: Zavod za udžbenike i nastavna sredstva.

Milić, A. (2007). Porodica. U: Mimica, Aljoša i Bogdanović, Marija (ed.) Sociološki rečnik. Beograd: Zavod za udžbenike, 414-415.

Popadić D. (1992). Socijalnopsihološka struktura pravne socijalizovanosti na adolescentom uzrastu, Doktorska disertacija. Beograd: Filozofski fakultet.

Rohner R.P. (1975) They Love Me, They Love Me Not: A Worldwide Study of the Effects of Parental Acceptance and Rejection. Hew Haven: HRAF press.

Rohner R.P. (1978). Parental Acceptance-rejection Theory and the Phylogenetic Model, Ann Arbor, ERIC Clearinghouse on Counseling and Personnel Services, Document ED 151918.

Rohner R.P., \& Nielsen C. (1978) Parental Acceptance and Rejection: A Review and Annotated Bibliography of Research and Theory. 2 vols. New Haven: HRAF Press.

Rohner E.C., Rohner R.P. \& Roll S. (1980). Perceived Parental Acceptancerejection and Children's Reported Behavioral Disposition: A Comparative and Intracultural Study of American and Mexican Children. Journal of Cross-Cultural Psychology, 11, 213-231.

Rohner R.P. \& Rohner E.C. (1980). Antecedents and Consequences of Parental Rejection: A Theory of Emotional Abuse. Child Abuse and Neglect, The International Journal. 4, 189-198.

Rohner R.P. \& Frampton S. (1982). Perceived Parental Acceptance-rejection 
and Artistic Preference: an Unexplained Contradiction. Journal of Cross-Cultural Psychology, 13, 250-259.

Rohner R.P. (1984). Handbook for the Study of Parental Acceptance and Rejection, Meassurement of Parental Acceptance-Rejection and Its Social-Emotional Consequences, Centaer for the Study of Parental Acceptance and Rejection, The University of Connecticut Stories, CT., 06268 USA.

Stott , John R. W. (1991). Tumačenje Ivanovih poslanica, Novozavjetni Komentari, Novi Sad: Dobra Vest.

Sveto pismo staroga i novoga zaveta, Britansko i inostrano biblijsko društvo, Beograd.

Volin, Stiven Dž. i Sibil Volin (1996). Rezilijentna ličnost. Kako preživeli iz problematičnih porodica prevazilaze teškoće? Beograd: Prosveta.

Šušnjić, Đuro (1998). Religija I i II. Beograd: Čigoja štampa.

Zorica Kuburić

\section{CONCRETIZATION OF THE IDEA OF LOVE IN THEOLOGICAL MESSAGES AND PARENTAL BEHAVIOR ${ }^{2}$}

\section{Summary}

Based on empirical researches of parental behavior in the process of socialization and also on Rohner's parental acceptance-rejection theory, this paper raises an issue of love. In parental behavior that is perceived by a child, love is recognized as a motive that makes a child feel accepted. Rejected children accumulate fear and form a negative self-image. The family mediates between the accepted value system of the religious culture to which they belong and new generations in the process of socialization. From the perspective of Christianity ideal concepts of God and love are seen as synonyms. Experiences with parents and significant persons during the early childhood are related to the theoretical concept of attitude toward authority and its power. On a theoretical level, two ideas about God are intertwined: God who is in his own nature love, who loves, protects, forgives, saves; and/or God who controls,

2 Prepared as a part of project "Changes in social structure and mobility as factors of European integrations of the Republic of Serbia, with special reference to AP Vojvodina" No. 179053 (20112014), which is financially supported by the Ministry of Science and Technological Development of the Republic of Serbia. 
punishes, judges, and destroys. In this way love and fear meet in a religious experience, concretize in a religious ritual practice and live in everyday life of a family through parental behavior in the process of socialization.

Key words: love, fear, acceptance, rejection, parental behavior, parents, God. 